\title{
AMERICAN PERSPECTIVES
}

The National Self-image in the Twentieth Century

Library of Congress Series in

American Civilization

Edited by Ralph Henry Gabriel 



\section{AMERICAN \\ PERSPECTIVES}

THE NATIONAL SELF-IMAGE

IN THE TWENTIETH CENTURY

Edited for The American Studies Association by

ROBERT E. SPILLER and ERIC LARRABEE

Associate Editors:

RALPH HENRY GABRIEL

HENRY NASH SMITH

EDWARD N. WATERS

HARVARD UNIVERSITY PRESS - CAMBRIDGE - 1961 
(C) Copyright 1961 by the President and Fellows of Harvard College All rights reserved

Distributed in Great Britain by Oxford University Press, London

Library of Congress Catalog Card Number 61-8841

Printed in the United States of America 